\title{
脊髄腫瘍による脊髄性くも膜下出血について
}

公立社院整形外科
大 浜
国 光 一 満 - 野 田 裕
山陰労災病院整形外科
木 村

\section{Spinal Subarachnoid Hemorrhage due to Spinal Cord Tumor}

by

\author{
M. Oh-hama, K. Noda and K. Kunimitsu \\ from Department of Orthopedic Surgery, \\ Yashiro Hospital, Hyogo.

\section{Kimura} \\ Dept. of Orthop. Surg. San-in Rosai Hospital
}

Spinal subarachnoid hemorrhage ( $\mathrm{SAH}$ ) has the most common occurrence due to A-V malformation, but SAH from the spinal cord tumor is well documented. A case of SAH due to neurinoma of the spinal cord is reported. This case experienced the sudden onset ofsharp low back pain with radiation to both hips, and had the increasing loss of power. The early laminectomy revealed the neurinoma of the spinal cord at conus with intracapsular hematoma, and the extirpation of the tumor decreased the neurological deficit.

脊䯙性クモ膜下出血の原因としては, A-V malformation などの血管性病変によるすの，血小板減少症 などの血液病変によるもの，結節性動脈周囲炎による あのなどが報告されているが，脊髄腫瘍による出血は 比較的稀机とされる. 1930 年, Andre-Thomas によ る ependymoma からの脊髄性クモ膜下出血例 の 報 告以来，いくつかの 報告例を散見するのみである.

Iob 弓（1980 年）は脊䯣腫瘍の unusual onset とし てのクモ膜下出血例をまとめ, 自験例を含め報告して いる．乙れらの報告によると，原因となる脊髄腫愓は ependymoma や neurinoma が多く, 他に meningioma, astrocytoma, sarcoma, hemangioblastoma があり, 一般に若年者に多発し, 発生部位とし ては脊髄円錐部から馬尾神経にかけて多くみられると されている。

本症は, 早期の椎弓切除術による脊䯣腫瘍摘出術が 必要である疾患として重要である。最近, 我々は脊䯣 円錐部の neurinoma を原因として発症した脊䯣性
クモ膜下出血の 1 例を経験したので文献的考察を加え 報告する。

\section{症例}

\section{2 才, 男性, 農業}

主訴：腰痛および両下肢機能障害

現病歴：数年前より中腰位作業にて腰痛あるも農作 業可能なため放置していた.

昭和 56 年 8 月 22 日，いつも通りの農作業中，突然 激裂な腰痛をきたし，這うょうにして自宅へ䚻り安静 臥床するも腰痛が持続した，翌日，腰痛著明のため近 医受診し入院となる.入院後安静により腰痛は徐々に 軽快したが， 8 月 27 日朝より両下肢脱力著明となり 歩行不能となった. 同時に尿失禁, 両下肢異常知覚が 出現し，ただちにステロイド剤の投与をうけたが，両 下肢機能障害は増悪した． 9 月 1 日，当院を紹介され 入院となる.

既往歴： 2 年前, 前立腺肥大症にて外科的治療. 
家族歴・生活歴：特記すべきことなし．

\section{初診時所見}

歩行不能のため車イスで来院. 意識清明, 頭痛 $(-)$, 悪心嘔吐 $(-)$, 項部硬直 $(-)$, 両上肢運動知覚障害 (一), 両上肢腱反射正常.

腰椎可動制限が著明で， $\mathrm{L}_{1}$ 棘突起吒打痛，手掌圧 痛を認めた。両下肢腱反射消失，病的反射 (一), 右 $\mathrm{L}_{3}$ 䯣節以下, 左 $\mathrm{L}_{4}$ 䯣節以下にあらゅる知覚の低下 を認来梢治強い，両下肢筋力は $2 \sim 1$ であり，骨盤 周囲筋力の低下が著しく，ひとり立ち不能であった （図 1 ）。また膀胱直腸障害を認めた。
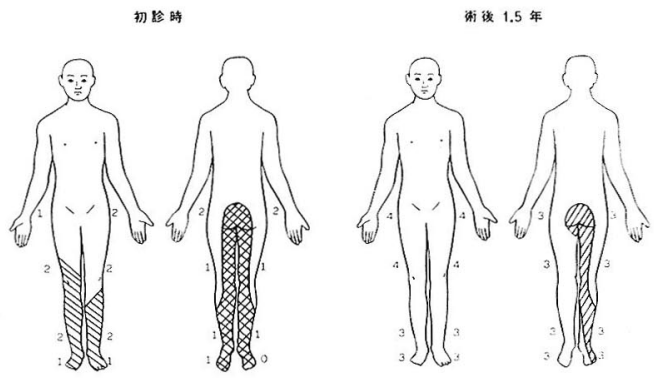

図1 初診恃および術後 1.5 年の筋力（数字）と

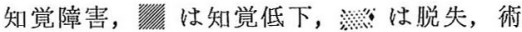
前筋力 $2 \sim 1$ が術後 $4 \sim 3$ と改善し独歩可 能となる。

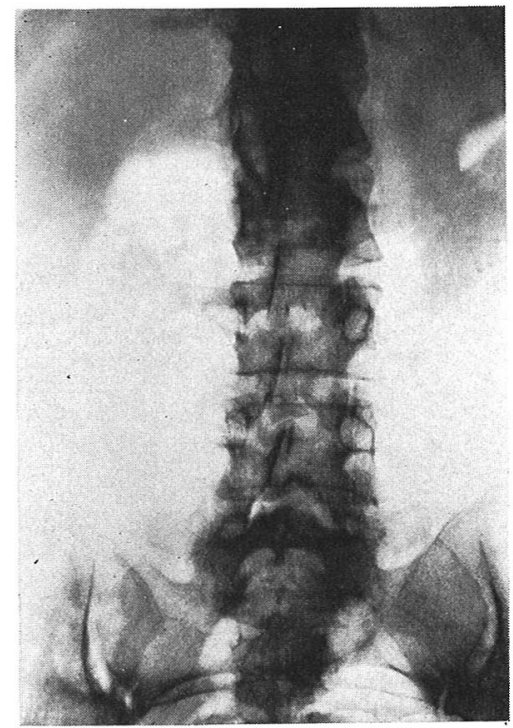

図2 単純エックス線像. $\mathrm{Th}_{12} \sim \mathrm{L}_{2}$ に椎弓根の 菲薄化を認める

\section{エックス線像と C T 像}

初胗時の単純エックス線像では全般的に脊椎の加令 的変化があり, $\mathrm{Th}_{12} \sim \mathrm{L}_{2}$ に椎弓根の菲薄化を認め, 脊 柱管はいわゆる balooning の状態であった（図 2). 前額面断層撮影や CT 像でもこの balooning をよ り明確に認めたが (図 3 ), 腫瘍陰影は enhancement そてひ明らかにできなかった。

\section{検査所見}

血液一般，肝機能，腎機能検查飞おいて異常所見を 認めず，また，出血傾向む認められなかった。

入院後の $L_{4 / 5}$ 穿刺による䯣液所見としては，初圧

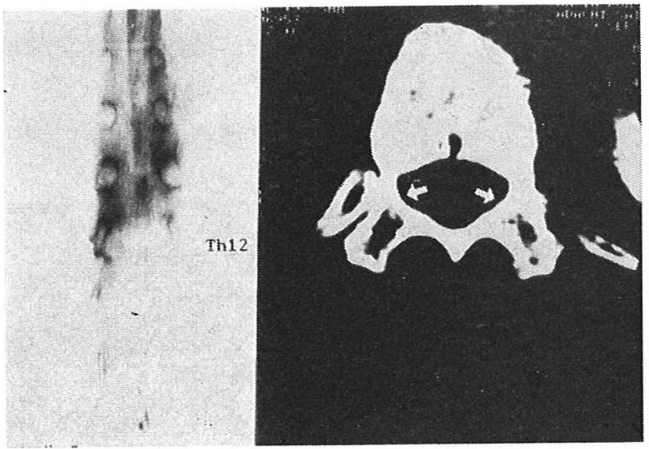

図3前額面断層撮影像と C T 像 椎弓根部の韭薄化と脊柱管の balooning が著明 である。

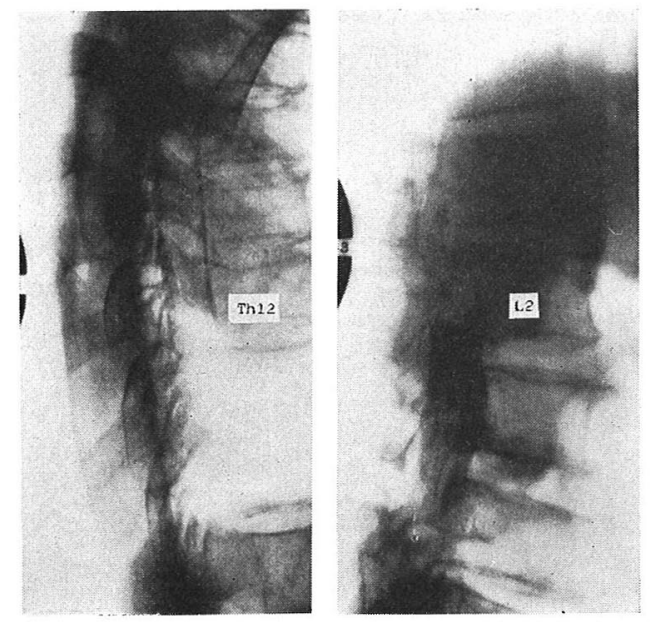

図4 Metrizamied myelogram

上行性には $\mathrm{L}_{2}$ 下縁, 下行性には $\mathrm{Th}_{10}$ 下縁にて 完全プロック像を呈し，騎袴状である。 
$120 \mathrm{mmH}_{2} \mathrm{O}$, xanthochromia t, Queckenstadt test 上昇一, 終圧 $0 \mathrm{mmH}_{2} \mathrm{O}$ ( $2 \mathrm{ml}$ 採取後), 細胞多 数 (多くは赤血球), protein $3500 \mathrm{mg} / \mathrm{dl}$, 糖 $31 \mathrm{mg}$ $/ \mathrm{dl}$.

\section{脊㵦造影所見}

Metrizamide $250 \mathrm{mgI} / \mathrm{ml}, 5 \mathrm{ml}$ 注入による $\mathrm{my}$ elography では $\mathrm{L}_{2}$ 下縁にて上行性に 完全ブロック 像を認め騎営状を呈していた，後頭窩穿刺による下行 性 myelography では $\mathrm{Th}_{10}$ 椎体下縁で 停止像を示 した (図 4). CT myelogram では $\mathrm{Th}_{11} \mathrm{~L}_{2}$ にクモ 膜下腔の造影剂眝留を認めなかった。

\section{入院後経過}

入院後ひきつづきステロイド戍と止血剤の投与を行 なったが，図 1 に示すでとく初晾時に骨盤周囲筋が 2 〜 1であり，それより末梢側す 2 ～1 筋力が保たれ ていたにもかかわらず，経過中に漸時増悪し末梢側筋

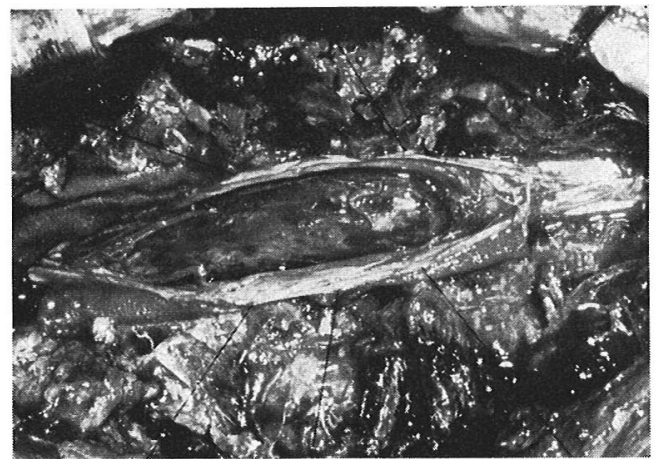

図 5 術中所見

硬膜切開で脊髓円錐部に腫瘍をみる。

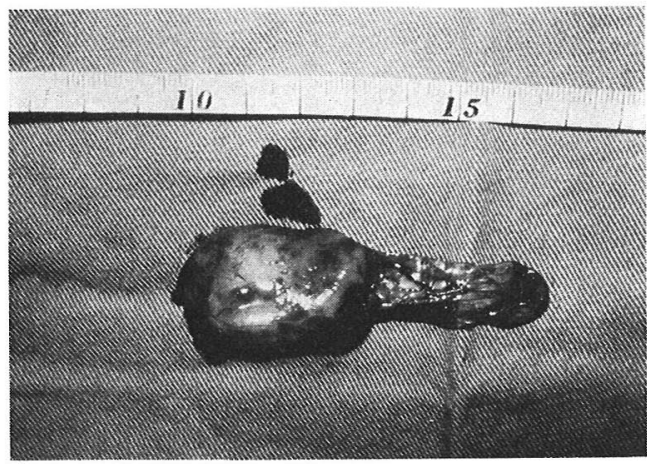

図6 摘出標本

長径 $3 \mathrm{~cm}$, 横 $2 \mathrm{~cm}$ の腫瘍と皮膜を共にする血腫 がある。
カは 0 となった。また膀胱内圧測定でも hypotonic bladder の謬断を得た。

\section{手術時所見}

9 月 10 日，発症より 20 日目に $\mathrm{Th}_{10} \mathrm{~L}_{3}$ の椎弓切 除術を施行した. $\mathrm{Th}_{12}{ }^{2} \mathrm{~L}_{2}$ の椎弓は著明に菲薄化して おり硬膜外脂肪組織はほとんご見られなかった。硬膜 は黒っぽく変色し除圧と共に膨隆するも硬膜外には出 血巣を認めなかった，硬膜切開で図 5 に示すように, $\mathrm{L}_{12}$ 亿長径 $3 \mathrm{~cm}$, 横径 $2 \mathrm{~cm}$ の表面平滑な腫儫があ り，中枢側には皮膜をひとつにする血腫を認めた，血 腫の中枢端之腫瘍の尾側端は，脊㛚造影像の欠損高位 と一致していた。乙机らの腫瘍のため春䯣円錐部は腹 側へ強く圧排されていた（図５）。腫瘍は弾性硬であ り，血腫の一部が流出するも剥離摘出は比較的容易で あった（図6）。

\section{病理組織学的所見}

図 4 に示す摘出標本の組織学的検査では, 紡鍾型の 細胞によるパレード配列を示し， neurinoma と留断 した．腫瘍細胞間には多くの血管を認め，乙れが血の 原因之考えられた（図 7 ）。

\section{考察}

脊䯣腫瘍による脊髄性クモ膜下出血の報告は，調べ 得た範囲で 46 例（うち 1 例は本例）であった（表 1 ）. 原因となる腫瘍としては, ependymoma が 25 例 と 過半数をしめ, neurinoma 12 例, meningioma 3 例, astrocytoma 2 例, hemangioblastoma 2 例, sarcoma 1 例であった，発症年令は若年者に多く 10 〜20 代であり，15才以下の報告例が多い，腫瘍発生

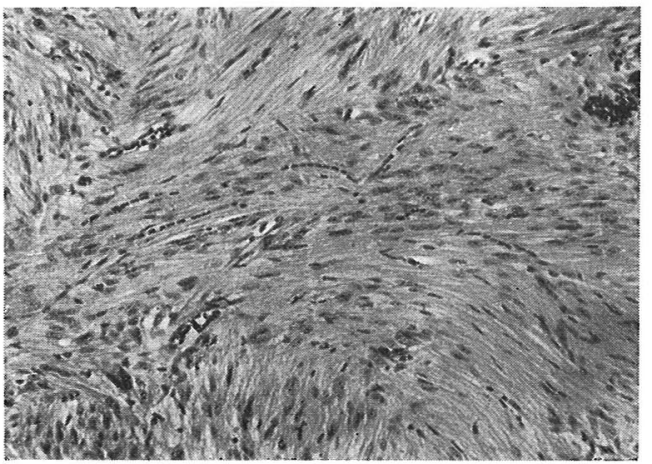

図 7 摘出標本の病理組織像 病理組織学的に neurinoma と畒断した。 
Table 1: Subarachnoid bleeding from spinal tumors
Ependymoma
1) Andre-Thomas, 1939
2) Bailey, 1935
3) Abbott, 1939
4) McCall, 1942
5) Brown, 1946
6) Paillas, 1950
7) Paillas, 1950
8) Woltmann, 1951
9) Fernandaz, 1956
10) Pernanbucano, 1957
11) Mendelsohn, 1958
12) Amici, 1959
13) Amici, 1959
14) Amici, 1959
15) Nassar, 1968
16) Nassar, 1968
17) Nassar, 1968
18) L'Vovskii, 1968
19) Payne, 1973
20) Buge, 1974
21) Nijensohn, 1974
22) Djindjian, 1978
23) Djindjian, 1978
24) Djindjian, 1978
25) Iob, 1980

Neurinoma

1) Mixter, 1937

2) Krayenbühl, 1947

3) Krayenbühl, 1947

4) Roger, 1947

5) Roger, 1949

6) Halpern, 1958

7) Prieto, 1967

8) Fortuna, 1968

9) Grollmuus, 1975

10) Djindjian, 1978

11) Luxon, 1978

12) Muhtaroglu, 1980

13) Oh-hama, 1982

Meningioma

1) Roger, 1949

2) Nassar, 1968

3) Toledo, 1981

Astrocytoma

1) Bhandari, 1969

2) Runnels, 1974

Hea mangioblastoma

1) Djindjian, 1978

2) Kormos, 1980

Sarcoma

1) Tarlov, 1953
$\mathrm{L}_{2 / 3}$ cauda

$\mathrm{L}_{1-4}$

$\mathrm{L}_{2 / 3}$

filum $\mathrm{t}$.

$\mathrm{L}_{4 / 5}$

$\mathrm{L}_{1 / 2}$

$\mathrm{T}_{9}-\mathrm{L}_{3}$

cauda

conus

filum $\mathrm{t}$.

filum $t$.

$\mathrm{L}_{3}$

cauda

$\mathrm{L}_{5}$

cauda

$\mathrm{L}_{1 / 2}$

filum $t$.

cauda

cauda

cauda

$\mathrm{L}_{3}$

cauda

filum $t$.

conus

$\mathrm{T}_{12} / \mathrm{L}_{1}$

$\mathrm{T}_{12}$

cauda

$\mathrm{L}_{3 / 4}$

cauda

$\mathrm{L}_{1-3}$

cauda

cauda

$\mathrm{T}_{8-11}$

$\mathrm{L}_{1}$

$\mathrm{C}_{3 / 4}$

cauda

conus

$\mathrm{L}_{\overline{5}}-\mathrm{S}_{2}$

filum $\mathrm{t}$.

$\mathrm{T}_{2}$

$\mathrm{T}_{9}$

$\mathrm{T}_{1 / 2}$

$\mathrm{L}_{2-4}$

$\mathrm{C}_{1}$

$\mathrm{C}_{3}-\mathrm{T}_{2}$
部位は頸髄から馬尾神経まで広範に分布するが，頸椎 3 , 胸椎 7 , 腰椎部 36 之脊䯣円椎部から馬尾にかけ て多くみられる，その発症には体動などによる minor trauma が関係しているといわれる. 本例は最す高令 における発症であり, すでに腫昜による春椎骨変化を 来たしているにあかかわらず，ほとんど症状を有さ ず，農作業による minor trauma によって脊髄円錐 部の血管に富む腫瘍から出血し発症したものと考えら れた。

脊䯣性クモ膜下出血の多くは，出血により突然その 支配領域に激裂な疼痛を来たし, 徐々に筋力低下, 知 覚障害, 排尿障害をきたすすのである.しかし，なか には再発性の疼痛を繰り返し, 徐々に出血による二次 性の脊䯣障害を引き起こすすのああり, また, 頸椎部 の脊䯣腫碭によるクモ膜下出血はあたかも頭蓋内クモ 膜下出血であるかのような症状を呈するあのあある.

診断としては, 脳脊䯣液検査による血液成分の証明 が重要であり，脊随造影所見が腫瘍確認の参考とな る. 本例も腰椎穿刺で明らかな出血を認め, 脊髄造影 像では脊髄円錐部に腫瘍陰影を認めた. また, Djindjian らは本症の診断に selective spinal angiography の重要性を強調している.

治療としては, できるだけ早期に椎弓切除術を施行 し, 腫寅の atraumatic な摘出が必要である. 他家 の報告によっても，早期に椎弓切除術による除圧と腫 瘍摘出により良好な結果を得ている. 本例も $\mathrm{Th}_{10} \sim$ $\mathrm{L}_{3}$ の椎弓切徐術後, かなりの筋力の回復がみられ, 現在は下肢筋力も $4 \sim 3$ となり, 1 本枝使用にて独歩 可能で日常生活む支障なく行なえている.

\section{ま と め}

脊髄腫儫による脊䯣性クモ膜下出血の 1 例を報告 し，本症は稀な疾患であるが，早期の惟弓切除術によ る腫啺摘出術が重要であると述べた.

\section{文献}

1) André-Thomas, et al.: Syndrome d'hemorrhagie méningée réalise par une tumeur de la queue de cheval. Paris méd., 77: 292-296, 1930.

2) Bhandri, Y. S. : Subarachnoid hemorrhage due to cervical cord tumor in a child. J. Neurosurg., 30: 749-751, 1969.

3) Djindjian, M., et al.: Subarachnoid he- 
morrhage due to intraspinal tumors. Surg. Neurol., 9: 223-229, 1978.

4) Grollmus, J.: Spinal subarachnoid hemorrhage with schwannoma. Acta Neurochir., 31: 253-256, 1975.

5) Iob, I., et al.: An unusual onset of a spinal cord tumour: Subarachnoid bleeding and papilloedema. Neurochirurgia, 23: 112116, 1980.

6) Kormos, R. L., et al.: Subarachnoid hemorrhage due to a spinal cord hemangioblastoma: Case report. Neurosurgery, 6: 657-660, 1980.

7) Luxon, L. M. and Harrison, M. J. G.: Subarachnoid hemorrhage and papilledema due to a cervical neurilemmoma. J. Neurosurg., 48: 1015-1018, 1978.

8) Mendelsohn, R. A. and Mora, F.: Spontaneous subarachnoid hemorrhage caused by ependymoma of filum terminale. J. Neurosurg., 15: 460-463, 1958.

9）宮崎雄二ら：脊䯣性〈子膜下出血の病理と臨 床。日本臨林，36，601-608，1978.

10) Muhraroglu, U. and Strenge, H.: Rezidivierende Subarachnoidalblutung bei spinalem Neurinom. Neurochirurgia, 23: 151155, 1980.

11) Nassar, S. I. and Correll, J. W.: Subarachnoid hemorrhage due to spinal cord tumors. Neurology, 18: 87-94, 1968.

12) Nijensohn, D. E., et al.: Repeated “occult" spinal subarachnoid hemorrhage and spinal cord ependymoma. Minn. Med., 57: 697-699, 1974.

13) Payne, N. S. and McDonald, J. V.: Rupture of spinal cord ependymoma. J. Neurosurg., 39: 662-665, 1973.

14) Prieto, A. and Cantu, R. C.: Spinal subarachnoid hemorrhage associated with neurofibroma of the cauda epuina. J. Neurosurg., 27: 63-69, 1967.

15) Runnels, J. B. and Hanbery, J. W.: Spontaneous subarachnoid hemorrhage associated with spinal cord tumor. J. Neurosurg., 39: 252-254, 1974.

16) Tarlov, I. M., et al.: Subarachnoid hemorrhage and tumor implants from spinal sarcoma in an infant. Neurology, 3: 384390, 1953.

17) Toledo, E., et al.: Spinal subdural hematoma associated with anticoagulant therapy in a patient with spinal meningioma. Neurosurgery, 8: 600-603, 1981.

質 問総合せき損センター 芝 啓一郎

腰椎穿刺にて liguor 精査を行っておられますが, 後頭窩穿刺にて liguor の性状を検査されておりまし たら御教示下さい. 